\title{
FISCAL DECENTRALIZATION \\ DETERMINANTS: ANALYSIS \\ OF THE EU COUNTRIES' CLUSTERED \\ SAMPLE IN PERIOD 1995-2015
}

\author{
Lenka Maličká, Slavomíra Martinková
}

\section{Introduction}

In industrial and developed countries, the restructuring of public sector increased the importance of fiscal decentralization in the second half of $20^{\text {th }}$ century. In Eastern Europe its implementation delayed to the 1990's. The decentralization of decision-making powers was supported by the fiscal federalism theory in the 1950's and 1960's (Oates, 2005) developed by Samuelson $(1954 ; 1955)$, Tiebout (1956), Musgrave (1959). In this period many famous authors as Olson, Buchanan, etc. published their ideas in the field of collective action (Zabkowicz, 2017). Famous is also the decentralization theorem formalized by Oates (1972) and the Leviathan hypothesis elaborated by Brennan and Buchanan (1980).

According to the Panizza (1999), World Bank (2001), Afonso and Hauptmeier (2009), Martinez-Vazquez and Canavire-Bacarreza (2012), Horváthová et al. (2012), and many other interested in the fiscal decentralization research, expenditure and revenue decentralization indicators are frequently used. However, tax decentralization and transfer dependence indicators suggested by Stegarescu (2004) or OECD eliminate their formality. Stegarescu (2005) uses measures based on tax autonomy and revenue decentralization to conduct revenue-based assessment of public sector decentralization, while according to RodríguezPose and Krøijer (2009, p. 15), transfers can in effect create negative incentives for subnational governments to mobilize own revenue. Aristovnik (2012) computes a fiscal decentralization index based on measuring the fiscal autonomy and fiscal importance of the local level of government.

According to the relevant literature, fiscal decentralization might be determined by several variables. Generally, according to Wagner's Law (Wagner, 1876), the GDP growth is connected with demand for public expenditures leading to expansion and decentralization of the public sector. This expectation was supported by Bodman et al. (2009) with the exception of low-income countries, MartinezVazquez and Canavire-Bacarreza (2012), Blume and Voigt (2008) or Panizza (1999). The relation of the unemployment rate to fiscal decentralization is investigated in Stegarescu (2004) considering declining revenue of the central government from taxes and social contributions in time of rising unemployment (case of revenue decentralization). Similarly behaves the dependency ratio. Bodman et al. (2009) satisfied their expectations about the negative influence of economic openness on fiscal decentralization, contrary to Stegarescu (2004). According to Bodman et al. (2009) the population density has no clear effect on fiscal decentralization, but its significant presence in estimation is obvious. Blume and Voigt (2008) investigated for the correlation between fiscal decentralization and total government expenditure (negative correlation). In case of Bodman et al. (2009), the total government's revenue expected positive effect is not obtained in case of expenditure decentralization. Assumptions about the inflation rate and public debt relation to fiscal decentralization follow the need of centrally provided decisions on macroeconomic level as mentions Oates (2005). In period of their increase, the future development of economy might worsen (Siničáková et al., 2017; Siničáková \& Gavurová, 2017), so the decision-making burden is taken to the central level of government ruling against decentralization. Expectations about local indebtedness relation to fiscal decentralization 
might postulate both effects. Positive, if the increase of local debt is connected with higher local authority (power to borrow). Negative one relies to need of local debt regulation on the central level in case of it extension what tends to reducing the power of localities. Finally, the area variable is investigated in Panizza (1999), Bodman et al. (2009) or Jílek (2015) without finding unanimous results supporting the idea of higher decentralization in large countries.

The aim of the paper is to investigate the fiscal decentralization determinants of the EU 28 countries analysing the period 19952015. The first chapter is focusing on related literature. It is followed by the chapter of methods and data. The third chapter presents obtained results and corresponding discussion. On the end, the conclusion and references are closing the paper.

\section{Literature Review}

According to Panizza (1999, p. 98), there exist some empirical regularities which explain differences in the level of fiscal centralization (and decentralization) among countries fiscal centralization (and decentralization) determinants. Bodman et al. (2009) define the fiscal decentralization as the amount of independent decision-making power involved in subnational provision of public services, expenditure and revenue decision in an economy. In their research, they investigate determinants of fiscal decentralization in a large sample of countries with a sub-sample of OECD countries and low income and high-income countries using various measures of fiscal decentralization. Their findings in the panel data analysis are about the ambiguity where signs of variables for different fiscal decentralization measures are differing. Martinez-Vazquez and Canavire-Bacarreza (2012) stressed the influence of the geography on the fiscal decentralization. Their work is based on the idea that geographically diverse countries show greater heterogeneity among their citizens, including their preferences and needs for public goods and services provision what requires the decentralized decision-making. Panizza's (1999) approach differs from other researchers. His interest focuses on fiscal centralization and investigates the impact of country size, ethnic fragmentation, and democracy. Despite the opposite approach, results essentially do not differ from those of others. Stegarescu (2004) analyses the vertical government structure. $\mathrm{He}$ is searching for the impact of economic integration on fiscal decentralization in OECD countries using the panel data. The indisputable contribution of Stegarescu (2005) remains on the fiscal decentralization measurement claiming the importance of own revenues especially tax revenues of lower government levels using the tax classification suggested by OECD expressing the degree of the local government tax power.

Fiscal decentralization includes the decentralization of the tax power. Decisions in the field of taxation made by governments on different levels of government might lead to tax competition. The problem of tax competition is elaborated in a huge body of literature. The implausible impact of tax competition among localities was described in Oates (1972). It prevents localities from providing an efficient level of public good. Localities while vying for the mobile tax base decrease tax rates in sense of beggar-thy-neighbour competition (Jha, 2015). This leads to drop-out in tax revenues, total local revenues and finally to cuts in the expenditure side of local budgets. In this way, the under- provisioning of the local good comes and the described reality is known as a raceto-the-bottom hypothesis (see e.g. Razin \& Sadka, 2011; Stansel, 2006 or Mendoza \& Tesar, 2005). Lachet-Touya (2016) describes both vertical and horizontal tax competition in a common agency game. Gonzales-Eiras and Niepelt (2016) propose tax centralization and intergovernmental grants contrary to fiscal decentralization principles given by Oates (1999). Other forms of competition at the local government level regarding the Tiebout's idea are investigated in Blazquez-Fernández et al. (2017). Here the quality of public good provided by lower government units causes the crossborder mobility.

Wide literature is focusing on investigating the impact of fiscal decentralization on chosen macroeconomic indicators. In the spirit of the Brennan and Buchanan's Leviathan hypothesis, further research consists in "searching for Leviathan". Marlow (1988), Oates (1985; 1989), Rodden (2003) or Crowley and Sobel (2011) are searching for constraining effect of fiscal decentralization on the government expenditure with different results. Often solved is also a question about the fiscal decentralization impact on public debt of EU 
countries as provides Horváthová et al. (2012) or Afonso and Hauptmeier (2009). Results show the positive impact of revenue decentralization on public debt in the research of Horváthová et al. (2012) and the negative impact of the expenditure decentralization on a primary balance in case of Afonso and Hauptmeier (2009). Research focusing on investigating the relationship between fiscal decentralization and economic growth covers studies of RodriguezPose and Krøijer (2009) or Rodriguez-Pose and Ezcurra (2011). Analysis of this problem in countries of Central and Eastern Europe, and in OECD countries resulted in revealing the significant negative impact of fiscal decentralization on economic performance, what interrupts the highlighted positive image of fiscal decentralization. Earlier, Akai et al. (2004) observed a positive relationship, and Akai et al. (2007) observed a hump-shaped relationship between fiscal decentralization and economic growth similarly to the Thießen (2003).

\section{Methods and Data}

Paper divides EU countries into more homogenous groups using the cluster analysis to reduce the diversity among countries regarding the rate of fiscal decentralization. Classification of countries according to the degree (or rate) of fiscal decentralization is also proposed by Akai et al. (2004). Clustering, as a type of data segmentation, allows creating groups with the most possible similarity inside the group and the possible distance among groups (Řezánková et al., 2009). EU countries are divided according to hierarchical clustering based on Euclidean distance and Ward method. Decomposition into clusters serves as input to the regression analysis based on panel data approach and diminishes the intercountry heterogeneity in the level of fiscal decentralization. This facilitates to reduce the possibility of omitting certain specifics.
Longitudinal data cover period from 1995 to 2015 on annual base (with some exceptions of countries without complete datasets as Croatia). The paper follows the panel data approach based on estimating the most frequently used models for panels (longitudinal or crosssectional time-series data). The adequacy of pooled OLS, fixed-effects (FEM) and randomeffects model (REM) is tested. First, for each cluster and each fiscal decentralization indicator, the pooled OLS models are estimated, and they are tested against the adequacy of FEM or REM. Panel diagnostic refers the adequacy of the pooled OLS or FEM and REM (Greene, 2011). The Hausman test is used to decide between FEM and REM model (Baltagi, 2001). If the null hypothesis that GLS estimates are consistent is rejected, FEM model is estimated. To avoid heteroskedasticity and autocorrelation, the robust HAC standard errors of Arellano type (Arellano \& Bond, 1991) was introduced in case of FEM models. REM models are arranged using the Swamy-Arora transformation. All further presented models are parsimonious. For each cluster were estimated four models regarding the way of fiscal decentralization indicator expression.

Prepared dataset includes data from Eurostat and AMECO. Data are analysed through the econometric program R 3.2.3 and program Gretl. Fiscal decentralization measures (see Tab. 1) are expressing the fiscal decentralization rate or degree of fiscal decentralization and have two roles in the research. Their averages create basics of clustering. Time series of expenditure decentralization (ExpDec), revenue decentralization (RevDec), tax decentralization (TaxDec) and grant decentralization (GrantDec) are dependent variables in panel estimations.

To identify the fiscal decentralization determinants macroeconomic, demographic or geographic and fiscal indicators are involved to the econometric analysis:

\section{Tab. 1: Fiscal decentralization measures}

\begin{tabular}{l|l}
\multicolumn{1}{c|}{ Measure } & \multicolumn{1}{c}{ Expression } \\
\hline ExpDec & Sub-national expenditure to total government expenditure \\
\hline RevDec & Sub-national revenue to total government revenue \\
\hline TaxDec & Sub-national tax revenue to sub-national total revenue \\
\hline GrantDec & Sub-national grants and transfers received to total sub-national revenues \\
\hline
\end{tabular}


Macroeconomic indicators are:

- GDP per capita growth (GDPpcgrowth),

- Economy openness (openessGDP) computed as a sum of Import and Export as $\%$ of GDP,

- Inflation rate based on the HICP index (inflHICP),

- Unemployment rate (unmp),

- Public debt as \% of GDP (PubDebtGDP).

Fiscal variables based on budget approach are:

- Total government revenues as \% of GDP (TotRevGDP),

- Local indebtedness as \% of GDP (LocDebtGDP).

Demographic and geographic variables involved to the research are:

- Population density (popdensity).

- Dependency ratio (dependencyratio) is computed as the share of the population less than 15 years and 65 years over on population in productive age.

- Area (area) in $\mathrm{km}^{2}$.

Research on fiscal decentralization determinants often stresses also other variables. According to the countries' sample and results of preliminary estimations, they are not involved to the further investigation. Panizza (1999) or Aristovnik (2012) introduced the democracy indicator to explain the variability fiscal decentralization. Maličká (2016) proceeded similarly without finding its significance on the European countries sample. The democracy degree of the EU country sample does not show any important dissimilarity among countries and is on a comparable level. Horváthová et al. (2012) or Bodman et al. (2009) deliberate over the constitution variable importance (federation, number of government levels, average size of local unit) expressing the origin of country's administrative structure determining conditions for fiscal decentralization implementation with ambiguous answers. Afonso and Hauptmeier (2009) searched for the importance of the elections variable without finding its significant influence. Stegarescu (2004) introduces dummy variables for second chamber of parliament with representatives delegated by the regions or a dummy variable for legal provisions concerning national and legislative referendums. Stegarescu (2004), Panizza (1999) or Martinez-
Vazquez and Canavire-Bacarreza (2012) involve to the research of fiscal decentralization (Panizza centralization) determinants indicators describing the linguistic or ethnic fragmentation. Excluding some exceptions (Belgium) the EU countries sample is not extensively ethnically and linguistically differentiated within country reviewing official languages and nations. Extending the country sample on e.g. OECD countries (Stegarescu, 2004) or some countries from America or Africa (Panizza, 1999; MartinezVazquez \& Canavire-Bacarreza, 2012) values of these indicators might vary.

\section{Results and Discussion \\ 3.1 Cluster Creation and Characteristics}

Different measures of fiscal decentralization mentioned in chapter 2 serve as input to the cluster analysis. EU countries were clustered according to fiscal decentralization average values. Scaling them and computing the distance matrix in $\mathrm{R}$ the final division is obtained. The average degree of fiscal decentralization according to ExpDec, RevDecand GrantDec was computed for 1995-2015, TaxDec 1995-2014. Malta's TaxDec was set as proxy 0 , studying the tax assignment in Malta. Croatia's ExpDec, RevDec and GrantDec averages are for 20012015, and TaxDec for 2002-2014 according to available data. Fiscal decentralization averages of EU countries according to different measure are displayed in Figure 1. The predefined scale divides EU countries in a following mode: 1 (the lightest shadow of grey) characterizes countries from $0 \%$ to $10 \%$ fiscal decentralization, 2 characterizes $11-20 \%$, 3 characterizes $21-30 \%, 4$ characterizes $31-40 \%$ and 5 characterizes 41 and more \% fiscal decentralization degree.

Optimal number of clusters relies on author opinion with regards on the binary tree dendrogram (see Fig. 2). The optimum set by authors is three clusters. According to the clusters' summary data, clusters in the dendrogram are located as following. From the left to the right side the first is situated cluster 2 , then cluster 3 and cluster 1 . It is necessary to notice the structure of the cluster 1 , where three countries (Malta, Greece and Cyprus) are involved despite creating an isolated subcluster. In these three countries, the rate of fiscal decentralization is extremely low. In the next step of the research (panel estimation) are 


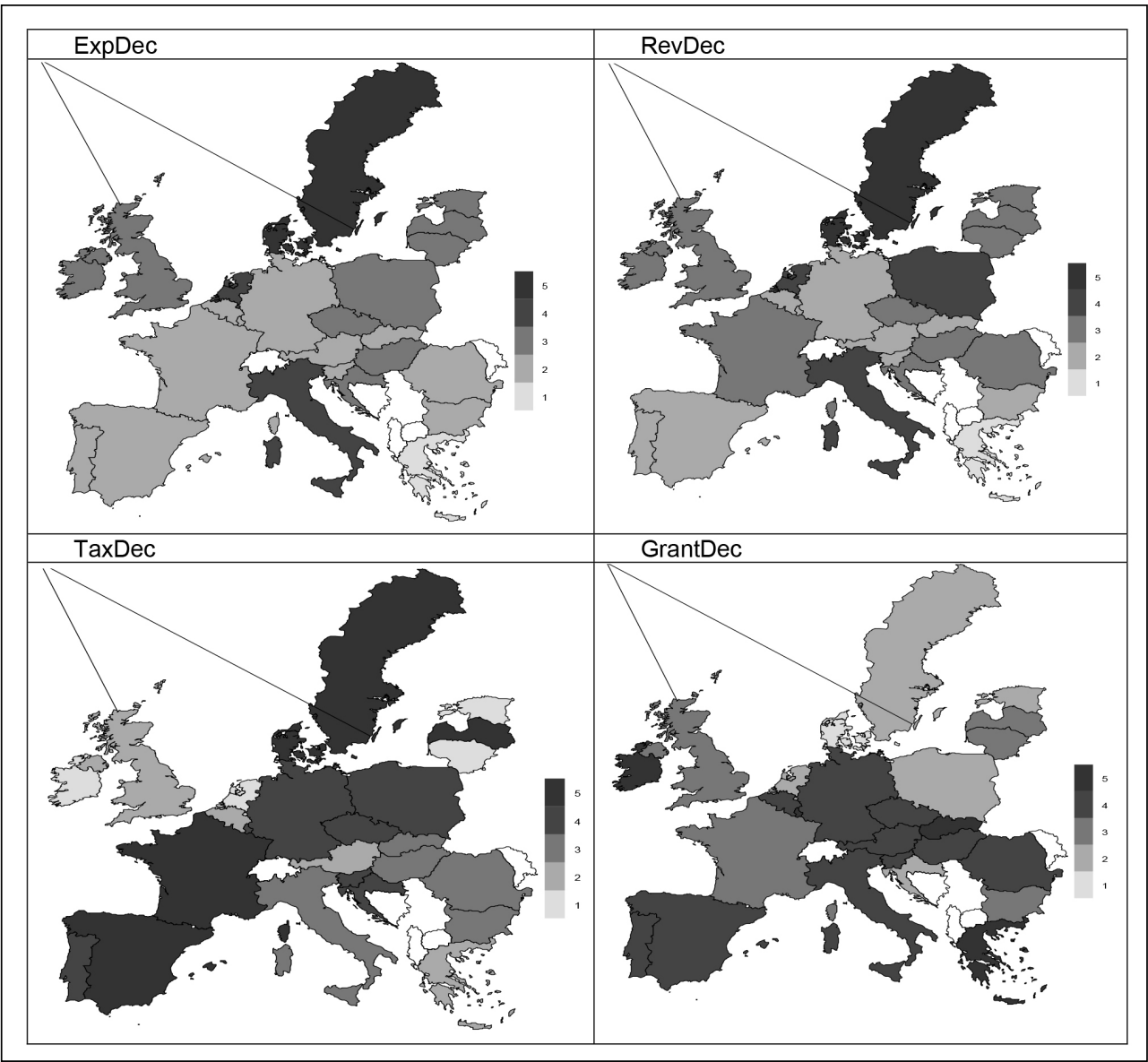

Source: own computation

Note: Malta and Cyprus are not displayed on the map, Malta due to small dimension, Cyprus due to map trim.

these countries excluded from the investigating.

Cluster 1 includes twelve EU countries. The body of the cluster is created by nine countries (excluding Malta, Greece and Cyprus). It contains two federal countries Belgium and Germany. In Spain the importance of regions is enhanced by the central government and they are provided by high autonomy (Stegarescu, 2004; Provazníková, 2015; Panizza, 1999). The importance of stronger and autonomous regions and municipalities also embodies in public support of the private sector provided by regional governments. It consists in creating better conditions that help to modernize the regional economy and to retain local sources as mentions Džupka et al. (2016, p. 54). Local resources are important also for the ability to attract investments (Martí et al., 2017). According to Afonso and Hauptmeier (2009, p. 6), Germany and Spain are characterized by pronounced fiscal federalism. In Germany, there is a vertical and horizontal system of revenue distribution (Hybka, 2016). France is decentralized territorially. Despite there is 


\section{Fig. 2: Cluster Dendrogram}

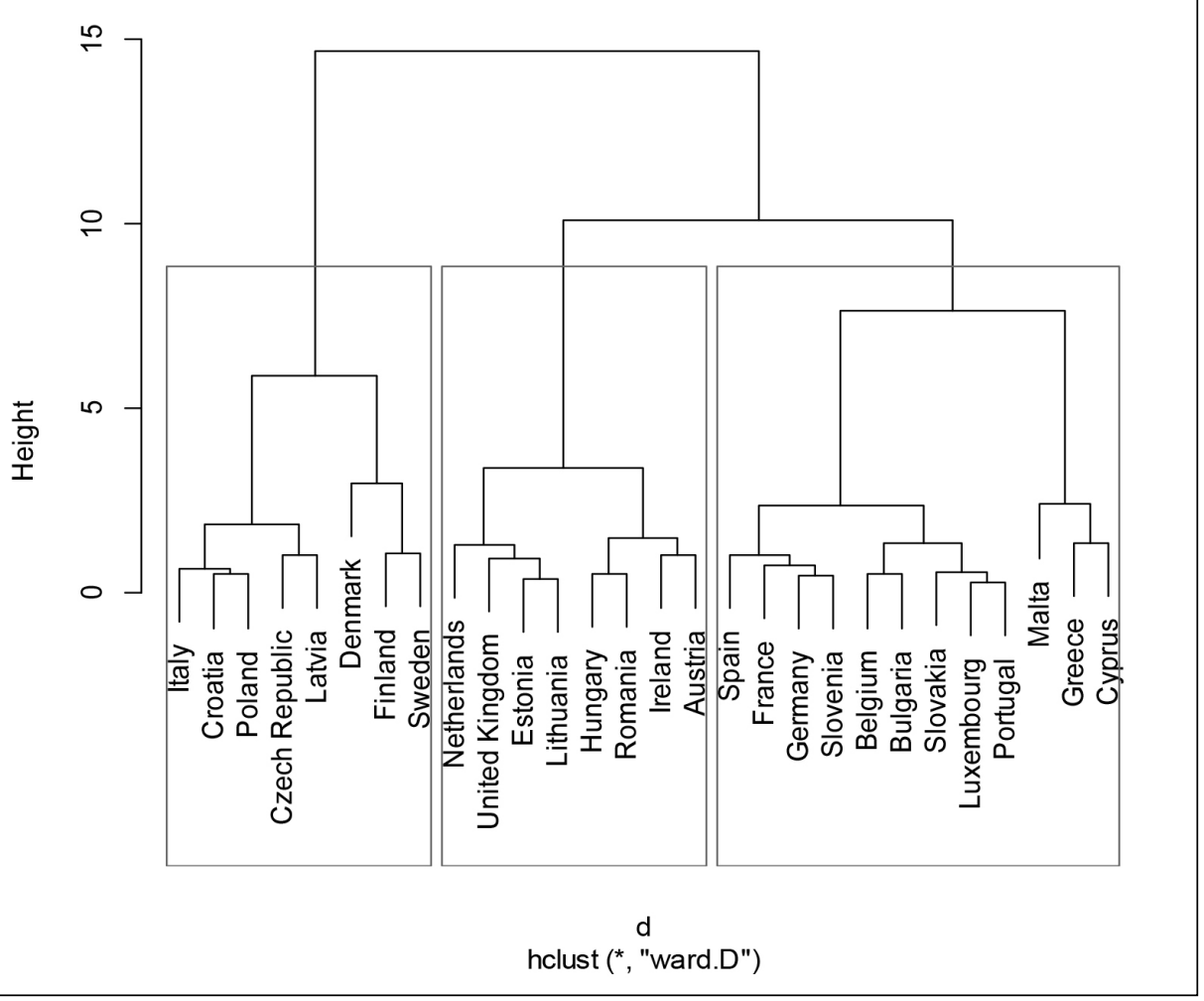

Source: own computation

a three-level local self-governance (regions, departments and municipalities), this country is rather centralized (Shah, 2007). Slovakia has established regional levels of government, contrary to countries as Bulgaria, Luxembourg, Portugal and Slovenia with self-governments only on municipal level. In comparison with other clusters, in cluster 1, values of ExpDec and RevDec are rather low. Values of TaxDec and GrantDec are higher. Malta, Greece and Cyprus are in the earlier step of hierarchical clustering classified to this cluster according to low expenditure and revenue decentralization and high-grant decentralization average values. The appearance of some countries (e.g. Germany or Slovakia) relies on the intensive inter-governmental grant flows.

Cluster 2 includes eight unitary EU countries. Most of them have multi-tiered local government (excluding Latvia which revised the resident structure of the country and established one-tier municipal government and republican cities with autonomous council according to Administrative territorial reform in 2009, Balodis et al., 2013). Finland and Sweden have certain regions established on experimental base (Provazníková, $2015)$ to test the decentralization eligibility. Italy has three-level local governance. The important role of regions (Provazníková, 2015; Panizza, 1999) is similarly to Spain in cluster 1. Cluster 2 differs from cluster 1 according to much higher ExpDec and RevDec average values. Values of the TaxDec indicator are rather high. Values of the GrantDec indicator are low.

In cluster 3, corresponding EU countries are unitary with exception of Austria (federation). However, Austria has two-tiered sub-national government as the prevalent part of the cluster 
countries. Estonia, Ireland and Lithuania have one-tier local government. In Lithuania and Ireland, the establishment of the regional selfgovernment was planned, although Ireland dropped this process. Estonia passed the administrative reform in 2016-2017 in aim to reduce the number of local elected bodies (Statistics Estonia, 2017). Average values of ExpDec and RevDec indicators of the cluster 3 are in the middle, in comparison with cluster 1 they are higher, but in comparison with cluster 2 they are lower (but closer to those of cluster 2). Average values of TaxDec indicator are low and values of GrantDec are also in the middle of the value range.

According to the clusters' composition, the structure of the public administration of the countries (number of sub-national levels of governments) differs inside the cluster. Cluster membership and corresponding average values of fiscal decentralization different measures indicate the different intensity of the fiscal decentralization. The results show that in some cases more administratively decentralized countries (with more than one level of local government) have lower share of sub-national expenditure or revenue on total government expenditure or revenue in comparison with onetier local government. E.g. in 2011 Hungary's regions and municipalities were dropped from some important responsibilities in favour of the central government. French regions and departments lost certain fiscal responsibilities in 2010 (Provazníková, 2015). Stegarescu (2004) discusses the high linguistic fragmentation in Belgium or Spain which led to the transfer of fiscal competencies and powers to regions and communities what supports quite high average TaxDec, despite low ExpDec and RevDec. Similarly to Stegarescu (2004), studies of Panizza (1999) or Martinez-Vazquez and CanavireBacarreza (2012) regard the indicator of ethnic fractionalization as important in the process of fiscal decentralization. The country sample of these two studies exceeds the EU countries sample. Panizza (1999, p. 10) mentions some of ethnic fractionalization index values. From European countries the highest degree of ethnic fractionalization is in Belgium (0.55), Switzerland (0.5). Yugoslavia was the European country with the highest degree of fractionalization (0.75). Currently, the prevalent part of former Yugoslavia countries is not an EU member, and also Switzerland is not an EU member.

\subsection{Panel Estimations}

For each cluster, four models are estimated according to the type of the fiscal decentralization measurement. Final estimations contain only statistically significant variables.

Results of cluster 1 estimations present statistically significant occurrence of the dependency ratio variable in all cases. Its negative relation to fiscal decentralization is observed in the ExpDec and RevDec model (see Tab. 2, column 2 and 3) matching the results of Stegarescu (2004), while his assumptions were different. In this group of countries, the adjustment of the division of public finance functions and public finance in a multi-order government is sensitive on the evolution of the share of the economic inactive population on total population. If the dependency ratio increases, the degree of expenditure and revenue decentralization decreases. Oppositely, Stegarescu (2004, p. 20) expected, that if the revenue from income taxes and social contribution decreases, it declines the central government revenue and ceteris paribus increases the degree of fiscal decentralization. The negative impact of the dependency ratio increase on fiscal decentralization might be caused by the higher reduction of certain local taxes connected to economic situation (in comparison with the reduction of central government revenue) in the most developed and core EU countries involved to this cluster. In Belgium these local taxes are additional income tax, in Germany, it is trading tax, in France, it is a local trading tax and municipal tax on income (Široký, 2009). Results obtained in case of TaxDec and GrantDec models might be explained by the sub-national revenue oriented fiscal decentralization indicators. The decrease of central government revenue in the period of decreased dependency ratio might cause cuts in transfers to subnational governments including revenues from shared tax. This diminishes the sub-national total revenue and thus increases the degree of fiscal decentralization.

Positive relation of population density on fiscal decentralization rate is observed in all cases. To support obtained results an argument is found in the available literature. According to Jílek (2015) larger countries decentralize more (considering the population as the country size measure). The increase of the population induces higher heterogeneity of preferences what desires a movement 
toward decentralization (Panizza, 1999). It is noticeable, that demographic variables are significant in a cluster, which contains the most populous EU countries (Germany, France, Spain, Belgium).
Observed negative sign of the openness variable coefficient in the ExpDec and TaxDec model matches the expectations and findings of Bodman et al. (2009). In cluster 1, countries as Belgium, Bulgaria, Luxembourg (extreme), Slovenia and Slovakia have high values of

\section{Tab. 2: Cluster 1, 2 and 3 estimations}

\begin{tabular}{|c|c|c|c|c|c|c|c|c|}
\hline \multirow{2}{*}{$\begin{array}{c}\text { Cluster } 1 \\
\text { variable } \\
\end{array}$} & \multicolumn{2}{|c|}{$\begin{array}{c}\text { ExpDec model } \\
\text { FEM }\end{array}$} & \multicolumn{2}{|c|}{$\begin{array}{c}\text { RevDec model } \\
\text { REM }\end{array}$} & \multicolumn{2}{|c|}{$\begin{array}{c}\text { TaxDec model } \\
\text { FEM }\end{array}$} & \multicolumn{2}{|c|}{$\begin{array}{c}\text { GrantDec model } \\
\text { REM }\end{array}$} \\
\hline & Coeff. & Signif. & Coeff. & Signif. & Coeff. & Signif. & Coeff. & Signif. \\
\hline intercept & 0.1578 & $* * *$ & 0.2411 & *** & -0.5980 & * & 0.0636 & \\
\hline dependencyratio & -0.0023 & ** & -0.0022 & *** & 0.0162 & $* * *$ & 0.0061 & ** \\
\hline opennessGDP & -0.0003 & $* * *$ & & & -0.0016 & $* * *$ & & \\
\hline popdensity & 0.0002 & * & 0.0001 & *** & 0.0024 & * & 0.0003 & $* * *$ \\
\hline LocDebtGDP & 0.0034 & ** & 0.0098 & $* * *$ & -0.0300 & $* * *$ & -0.0190 & ** \\
\hline PubDebtGDP & & & & & 0.0012 & ** & 0.0001 & $* * *$ \\
\hline $\operatorname{adjR2}$ & \multicolumn{2}{|c|}{0.29} & \multicolumn{2}{|c|}{0.30} & \multicolumn{2}{|c|}{0.44} & \multicolumn{2}{|c|}{0.46} \\
\hline
\end{tabular}

\begin{tabular}{|c|c|c|c|c|c|c|c|c|}
\hline \multirow{2}{*}{$\begin{array}{c}\text { Cluster } 2 \\
\text { variable }\end{array}$} & \multicolumn{2}{|c|}{$\begin{array}{l}\text { ExpDec model } \\
\text { REM }\end{array}$} & \multicolumn{2}{|c|}{$\begin{array}{c}\text { RevDec model } \\
\text { REM }\end{array}$} & \multicolumn{2}{|c|}{$\begin{array}{c}\text { TaxDec model } \\
\text { REM }\end{array}$} & \multicolumn{2}{|c|}{$\begin{array}{c}\text { GrantDec model } \\
\text { REM }\end{array}$} \\
\hline & Coeff. & Signif. & Coeff. & Signif. & Coeff. & Signif. & Coeff. & Signif. \\
\hline intercept & 0.3385 & $* * *$ & 0.3495 & $\star \star \star *$ & 0.3578 & $* * *$ & 0.6241 & *** \\
\hline opennessGDP & 0.0002 & ** & -0.0003 & * & 0.0008 & ** & & \\
\hline PubDebtGDP & -0.0008 & $* * *$ & -0.0004 & ** & 0.0018 & $* * *$ & & \\
\hline GDPpcgrowth & -0.0003 & * & -0.0005 & * & 0.0009 & * & 0.0010 & $* *$ \\
\hline LocDebtGDP & 0.0081 & *** & 0.0152 & *** & -0.0199 & $* * *$ & 0.0106 & *** \\
\hline inflHICP & 0.0022 & *** & 0.0021 & ** & & & & \\
\hline dependencyratio & & & & & & & -0.0093 & $* * *$ \\
\hline $\operatorname{adjR2}$ & \multicolumn{2}{|c|}{0.47} & \multicolumn{2}{|c|}{0.47} & \multicolumn{2}{|c|}{0.36} & \multicolumn{2}{|c|}{0.21} \\
\hline
\end{tabular}

\begin{tabular}{|c|c|c|c|c|c|c|c|c|}
\hline \multirow{2}{*}{$\begin{array}{l}\text { Cluster } 3 \\
\text { variable }\end{array}$} & \multicolumn{2}{|c|}{$\begin{array}{c}\text { ExpDec model } \\
\text { REM }\end{array}$} & \multicolumn{2}{|c|}{$\begin{array}{c}\text { RevDec model } \\
\text { REM }\end{array}$} & \multicolumn{2}{|c|}{$\begin{array}{c}\text { TaxDec model } \\
\text { REM }\end{array}$} & \multicolumn{2}{|c|}{$\begin{array}{c}\text { GrantDec model } \\
\text { REM }\end{array}$} \\
\hline & Coeff. & Signif. & Coeff. & Signif. & Coeff. & Signif. & Coeff. & Signif. \\
\hline intercept & 0.3624 & $* * *$ & 0.3196 & *** & 0.1231 & *** & 0.1315 & *** \\
\hline opennessGDP & -0.0004 & * & -0.0003 & * & & & 0.0013 & *** \\
\hline PubDebtGDP & -0.0015 & $* * *$ & -0.0012 & $* * *$ & 0.0010 & $* * *$ & -0.0113 & $* * *$ \\
\hline GDPpcgrowth & & & & & 0.0012 & * & 0.0012 & * \\
\hline inflHICP & -0.0013 & $* * *$ & -0.0011 & $\star * *$ & 0.0036 & $* * *$ & 0.0008 & $* *$ \\
\hline LocDebtGDP & & & 0.0116 & $* * *$ & -0.0134 & $* * *$ & -0.0090 & * \\
\hline $\operatorname{adjR2}$ & \multicolumn{2}{|c|}{0.33} & \multicolumn{2}{|c|}{0.30} & \multicolumn{2}{|c|}{0.47} & \multicolumn{2}{|c|}{0.39} \\
\hline
\end{tabular}


openness (1995-2015 average openness of Belgium is $143 \%$ of GDP, Bulgaria $102 \%$ of GDP, Luxembourg 295\% of GDP, Slovenia $118 \%$ of GDP and Slovakia $143 \%$ of GDP). Taxes from international trade (export and import taxes) are mostly the central government revenue, what decreases the value of the fiscal decentralization indicator.

The relation of local debt to fiscal decentralization rate is positive in case of ExpDec and RevDec model. Taking and local use of returnable financial resources to finance local needs lead to increase of local revenue and local expenditure, what increases the degree of fiscal decentralization. In case of TaxDec and GrantDec models is the situation opposite. The local revenue from loans increases the sub-national total revenue, what decreases the degree of fiscal decentralization formally.

Public debt variable is significant only in TaxDec and GrantDec models. Its positive relation to fiscal decentralization rate might be caused by a situation, when public debt (prevalently created on the central level) exhausts the public budget, requires saving arrangements, what reduces the amount of transfers shifted to sub-national level. This decreases sub-national total revenue and increases formally the degree of fiscal decentralization. E.g. in many of cluster countries (Belgium, Spain, France, Portugal, Slovenia or Germany) currently the public debt exceeds the Maastricht criterion, and since the financial crisis, transfers received by subnational governments decreased.

Results of cluster 2 estimations reveal some additional factors determining the fiscal decentralization in related countries. Here, in comparison with estimations for cluster 1 , the significant appearance of the GDP per capita growth variable and inflation rate variable is present. In the case of the GDP per capita growth variable, the ExpDec and RevDec models results follow the basics of the Wagner's Law. The increase of GDP per capita growth increases the public expenditure in developed countries. In post-communist countries involved to the cluster (Czech Republic, Poland, Latvia and Croatia as a member of former Yugoslavia), additional sources served to finance capital investments or other reforms made by central government level. Thus the increase of GDP per capita growth induces decrease of the fiscal decentralization rate. Results of the TaxDec and
GrantDec models reveal the formal tendency to more decentralization with respect of finance concentrated in the central budget in expense of shifting them to sub-national budgets, reducing the sub-national total revenues.

In the case of cluster 2 countries, the openness variable behaves contrary to expectation. It might be caused by the lower level of openness in these countries. In comparison with cluster 1, where Luxembourg is opened to $295 \%$ of GDP (1995-2015 average), Italy as one of the most developed countries in cluster 2 , reaches the average of $50 \%$ of GDP, Poland $71 \%$ of GDP, Finland $73 \%$ of GDP or Sweden $81 \%$ of GDP.

The mismatch with expectations is obtained in case of the inflation rate, where results show positive relation between inflation rate and expenditure and revenue decentralization. The explanation might be found in a theoretically oriented literature by the uncoordinated government activity, when in the period of increasing inflation rate, the government transfers responsibilities to sub-national level, even if the sub-national government level is not able to contribute to stabilization of the economy (Musgrave, 1959; Oates, 2005; Jha, 2015). In monitored period, the financial crisis disturbed the economic development of many countries which faced the public sector reforms. In 2007-2008, the inflation rate increased in all cluster countries. In the Czech Republic, the inflation rate doubled, and the expenditure and revenue decentralization increased stably from 1999 to 2008 (Jílek, 2009).

Public debt's impact on expenditure and revenue decentralization is negative in accordance with theoretical assumptions. The dramatic increase of public debt is obvious almost in all cluster countries after the financial crisis except of Latvia, Poland and Sweden, while the expenditure and revenue decentralization indicators diminished moderately or stagnated in this period (except of Sweden, where these indicators increased continually).

Local debt's relation to fiscal decentralization is positive in the ExpDec, RevDec and GrantDec models. Here again, the option of using returnable financial resources by sub-national governments might mirror in both local budget sides. Firstly, it appears in the revenue side of sub-national budgets as received loans. Correspondingly it appears in the expenditure side as capital 
expenditure and consequently principal and interest payments.

Dependency ratio is statistically significant once, in the GrantDec model, and its relation to fiscal decentralization is negative. It is notable that in all cluster countries the share of economically inactive population on total population is increasing. This invokes pressure on central governments redistributive activities financed from central budget in expense of subnational needs.

Results of cluster 3 estimations show negative effect of openness variable on fiscal decentralization in the case of ExpDec and RevDec models. Similarly to cluster 1 , in countries as Estonia, Lithuania, Ireland and Netherlands openness values increased during the monitored period and in 2015 reached levels over $150 \%$ of GDP, Ireland even $216 \%$ of GDP. As is mentioned hereinbefore, export and import taxes are revenue of central government, what decreases the value of the fiscal decentralization indicator.

The increase of GDP per capita growth induces increase of the fiscal decentralization rate in the case of TaxDec and GrantDec models. Similarly to results of cluster 2, possible reduction of sub-national total revenue due to realizing investment activities on central government level, might formally increase a fiscal decentralization degree. The need of building up the infrastructure (e.g. highways) was satisfied in post-communist economies as Hungary or Romania. In Estonia, massive public sector reforms were realized. In Lithuania, the program of restrictive reforms was implemented in 2008 after the financial crisis. (Ministry of Foreign and European Affairs of the Slovak Republic, 2017)

Relation between public debt and fiscal decentralization is negative supporting the expectation in case of ExpDec and RevDec models. Unclear rests the explanation of its significant appearance in the TaxDec and GrantDec models, where surprisingly the coefficient signs differ in these two cases. The result for the GrantDec model might be explained by the decreased amount of grants shifted to the sub-national government level in period of public debt increase.

For this group of countries, the inflation rate variable behaves in accord with expectations about its negative relation to fiscal decentralization. The increase of inflation rate influences the decrease of degree of expenditure and revenue decentralization. As mention Siničáková and Gavurová (2017), raise of inflation worsens the economic condition in a country. Following the idea of Musgrave (1959) revived e.g. by Oates (2005), centrally provided stabilization of the economy is desired in expense of further fiscal decentralization. Positive nature of the relation in the question in the case of TaxDec and GrantDec model might be caused by the decline of sub-national total revenue in the time of realizing stabilization arrangements on central level.

Local debt's relation to fiscal decentralization is positive in the RevDec model, but negative in the TaxDec and GrantDec model. This effect might be caused by the central regulation of local indebtedness. In Hungary, local governments suffered from inadequate shift of responsibilities and resources. It led to excessive indebtedness on municipal level. This encouraged the central government to withdraw certain part of their responsibilities and autonomy, what decreased the fiscal decentralization (Reuters, 2012).

\subsection{Discussion}

Main findings of the cluster analysis point to the different level of fiscal decentralization in countries with comparable government constitution what results in assignment of both unitary and federal states into a common cluster. It means that not all federations are equally decentralized and similar is the situation in case of one or/and multi-government unitary states. This is the principal reason for clustering the EU countries according to fiscal decentralization indicators. Regarding the promotion of the fiscal decentralization economic benefits in the literature, its implementation is evaluated as a positive move. Unfortunately, the theory does not give a recommendation or a guide about its optimal rate or degree. As the panel estimation results show, different political and socio-economic conditions in monitored countries necessitate a unique approach to realizing this process respecting the countries' particularity. For different clusters, the relation of investigated variables to fiscal decentralization varies and thus different factors are determining the fiscal decentralization. Results also show a need of concrete fiscal decentralization indicator revision. Prevalent part of results indicates contradictory relate of explanatory variables to basic but formal ExpDec and 
RevDec indicator in comparison with TaxDec and GrantDec indicator. In case of GrantDec fiscal decentralization indicator, it is obvious that the increase of grant flow intensity from the central government level has a reductive effect on the fiscal decentralization rate if considering the autonomous decision-making processes made at sub-national government level. The basic essence of this indicator expresses the dependency of lower levels of government on the central level. In the case of TaxDec, the question resists in the composition of sub-national tax revenues with accent on own tax revenues. If it is low, the shared tax revenues predominate, and these quasi-grants causes, that the $T a x D e c$ indicator behaves as GrantDec. Despite of mentioned, there are some common tendencies comparing the fiscal decentralization determinants for different clusters. Significant is presence of public and local debt variable, GDP per capita growth, openness and inflation rate, dependency ratio or population density variable.

Assumptions about variables' significance and their positive or negative impact on fiscal decentralization rate are not confirmed fully. Partial satisfaction is caused by several facts. Clusters are created on basis of fiscal decentralization indicator averages, but from the point of economic characterization of countries in the question, there can be abysmal differences. This embarrasses the panel estimation. Additionally, some models have to deal with low R2 (e.g. GrantDec estimation for cluster 2). Undeniable is the role of the fiscal decentralization indicator expression. However, Horváthová et al. (2012), Stegarescu (2004), Blume and Voigt (2008) or Bodman et al. (2009) stresses the formality of fiscal decentralization indicators. As ExpDec and $R e v D e c$ are regarded only as formal indicators and TaxDec and GrantDec stricter and more precise, results of estimations are different. The suggestion in this field provided by Stegarescu (2004) is related to the use of indicators which involve sub-national own revenues (especially own taxes, where locality controls the tax base and tax rate). This approach requires data rarely published in most of databases including the Eurostat, OECD or World Bank database. It is obvious that the construction of fiscal decentralization indicators is mirrored in observed results (see Tab. 2).

\section{Conclusions}

Identification of the fiscal decentralization determinants is provided in several steps. First, the fiscal decentralization rate in the EU countries is measured by different measures as expenditure, revenue, tax, and grant decentralization. Then their averages are computed to serve as input data to the cluster analysis. Classification of the EU countries into clusters makes groups of countries more homogenous regarding the fiscal decentralization different rates. This division into three groups is basic information to create panels. Accordingly, three different panels are set. For each panel four models are estimated to refer on the fiscal decentralization different measurement types. Results of estimation are confronted to assumptions based on related literature.

Identified determinants of the fiscal decentralization vary moderately according to cluster membership. Results of estimation revealed the dependence on construction of the fiscal decentralization measure. However, basic collision consists in the construction of expenditure and revenue decentralization measure in comparison with the tax and grant decentralization measure. While expenditure and revenue decentralization compares sub-national expenditure or revenue to total government expenditure or revenue, tax and grant decentralization are based on the share of a correspondent sub-item on sub-national total revenue. Though, this share is indirectly dependent on the central government decisions.

Results of the cluster 1 estimations present statistically significant relation between fiscal decentralization and dependency ratio, population density, openness, public and local debt. In cluster 2 it is the openness, GDP per capita growth, inflation rate, public and local debt and dependency ratio. Finally, cluster 3 estimations point to statistically significant impact of openness, GDP per capita growth, inflation rate and public and local debt on fiscal decentralization rate. Certain empirical regularities are observable. The openness variable has negative effect on fiscal decentralization degree in clusters, which include countries with high values of this variable. The growth of the GDP per capita is significant in clusters with half of membership created from post-communist countries. It is in negative relation with expenditure and revenue 
decentralization, contrary to positive effect in case of tax and grant decentralization. Impact of inflation rate on fiscal decentralization differs in clusters, but is positive in cluster, where all involved countries had to faced its increase in the time of financial crisis. Observed significant effect of demographic variables (dependency ratio and population density) mostly appears in cluster, which include the most populous EU countries. Public debt influences the expenditure and revenue decentralization negatively following the need of centrally provided stabilization, while in case of tax and grant decentralization is its effect positive due to the sub-national total revenue decline. Local debt is in prevalent parts in positive relationship with expenditure and revenue decentralization, when returnable financial resources increase sub-national revenue and correspondingly its expenditure, contrary to this effect in case of tax and grant decentralization.

The sensitivity of the estimation results on the fiscal decentralization measurement is obvious. Different measures lead to disunited results inside the cluster. Panels for clusters are sensitive also for their content. Involving all EU countries in one panel will probably bring similar results of unclear or contradictory nature. For the further research in this field, the extension of the cluster analysis input data is admissible. Naturally, final results will differ following the different division of countries into clusters.

The paper is published within project VEGA 1/0559/16.

\section{References}

Afonso, A., \& Hauptmeier, S. (2009). Fiscal Behaviour in the European Union: Rules, Fiscal Decentralization and Government Indebtedness (Paper no. 1054). Frankfurt Am Main, Germany: European Central Bank. Retrieved September 13, 2016, from https://www.ecb. europa.eu/pub/pdf/scpwps/ecbwp 1054. pdf?65329bbc7780082f990568f9ebddd89e.

Akai, N., Nishimura, Y., \& Sakata, M. (2004). Fiscal Decentralization, Economic Growth and Economic Volatility - Theory and Evidence from State-level Cross-section Data for the United States [Discussion Paper Series no. 03-F-2]. The Centre for International Trade Studies, Faculty of Economics, Yokohama National University.

Akai, N., Nishimura, Y., \& Sakata, M. (2007). Complementarity, fiscal decentralization and economic growth. Economics of Governance, 8(4), 339-362. https://dx.doi.org/10.1007/ s10101-007-0032-5.

AMECO. (2016). General government [Data file]. Retrieved September 27, 2016, from http:// ec.europa.eu/economy_finance/db_indicators/ ameco/index_en.htm.

Arellano, M., \& Bond, S. (1991). Some Tests of SpecificationforPanelData:Monte CarloEvidence and an Application to Employment Equations. The Review of Economic Studies, 58(2), 277-297. https://dx.doi.org/10.2307/2297968.

Aristovnik, A. (2012). Fiscal Decentralization in Eastern Europe: Trends and Selected Issues. Transylvanian Review of Administrative Sciences, 37, 5-22. https://dx.doi.org/10.2139/ ssrn.2187475.

Balodis, R., Kārkliņa, A., \& Danovskis, E. (2013). The Development of Constitutional and Administrative Law in Latvia after the Restoration of Independence. Law: Journal of the University of Latvia, 5, 44-119.

Baltagi, B. H. (2001). Econometric Analysis of Panel Data (2nd ed.). Chichester: John Wiley \& Sons, Ltd.

Blume, L., \& Voigt, S. (2008). Federalism and Decentralization - A Critical Survey of Frequently Used Indicators [Joint Discussion Paper Series in Economics, No.21-2008].

Blázquez-Fernández, C., Cantarero-Prieto, D., \& Pascual-Sáez, M. (2017). Patient CrossBorder Mobility: New Findings and Implications in Spanish Regions. Economics and Sociology, 10(1), 11-21. https://dx.doi.org/10.14254/2071789X.2017/10-1/1.

Bodman, P., Ford, K., Gole, T., \& Hodge, A. (2009). What drives Fiscal Decentralization? Retrieved July 27, 2016, from http://www. uq.edu.au/economics/mrg/3009.pdf.

Brennan, G., \& Buchanan, J. (1980). The Power to Tax: Analytical Foundations of a Fiscal Constitution. New York: Cambridge University Press.

Canavire-Bacarreza, G., \& MartinezVazquez, J. (2012). Reexamining The Determinants Of Fiscal Decentralization: What Is The Role of Geography? [Working Paper 12-11]. International Center for Public Policy. Retrieved August 14, 2016, from http://icepp. gsu.edu/files/2015/03/ispwp1211.pdf.

Crowley, G. R., \& Sobel, R. S. (2011). Does Fiscal Decentralization Constrain Leviathan? New Evidence from Local Property Tax Competition. Public Choice, 149(5), 5-30. 
https://dx.doi.org/10.1007/s11127-011-9826-7.

Džupka, P., Klasová, S., \& Kováč, V. (2016). Analysis of Innovative Start-Up Companies - Case of Košice Region. Quality Innovation Prosperity, 20(1), 40-56. https://dx.doi. org/10.12776/qip.v20i1.641.

Eurostat. (2016). Economy and Finance. Retrieved August 08, 2016, from http:// ec.europa.eu/eurostat/help/new-eurostatwebsite.

Gonzales-Eiras, M., \& Niepelt, D. (2016). Fiscal Federalism, Taxation and Grants [Working Paper 16.05]. Study Center Gerzensee. Retrieved September 16, 2016, from http://www.szgerzensee.ch/fileadmin/ Dateien.Anwender/Dokumente/workig-papers/ wp-1605.pdf.

Greene, W. (2011). Économétrie, Édition francophone (7th ed.). Pearson Education France.

Horváthová, L., Horváth, J., Gazda, V., \& Kubák, M. (2012). Fiscal Decentralization and Public Debt in the European Union. Lex Localis: Journal of Local Self-Government, 10(3), 265276. https://dx.doi.org/10.4335/10.3.265-276.

Hybka, M. M. (2016). Allocating Tax Revenue to Sub-Central Government Levels: Lessons from Germany and Poland. Equilibrium. Quarterly Journal of Economics and Economic Policy, 11(4), 689-709. http:// dx.doi.org/10.12775/EQUIL.2016.031.

Jha, P. Ch. (2015). Theory of fiscal federalism: an analysis. Journal of Social and Economic Development, 17(2), 241-259. https://dx.doi.org/10.1007/s40847-015-009-0.

Jílek, M. (2009). Fiscal Decentralization Ratios in Czech Republic. Acta Universitatis Bohemiae Meridionales, 12(3), 17-26.

Jílek, M. (2015). Factors of Tax Decentralization in OECD - Europe Countries. European Financial and Accounting Journal, 10(2), 33-49. https://dx.doi.org/10.18267/j.efaj.140.

Lachet-Touya, F. (2016). Horizontal and Vertical Tax Interactions in a Common Agency Game [CATT Working Paper No. 12]. Centre d'Analyse Théoretique et de Traitement des données économiques. Retrieved October 11, 2016, from http://catt.univ-pau.fr/live/.

Maličká, L. (2016). Determinants of Leviathan in the European Countries. Journal of Applied Economic Sciences, 11(1), 97-106.

Marlow, M. L. (1988). Fiscal Decentralization and Government Size. Public Choice, 56, 259269.
Martí, J., Alguacil, M., \& Orts, V. (2017). Location Choice of Spanish Multinational Firms in Developing and Transition Economies. Journal of Business Economics and Management, 18(2), 319-339. https://dx.doi.or g/10.3846/16111699.2015.1013980.

Mendoza, E. G., \& Tesar, L. L. (2005). Why Hasn't Tax Competition Triggered a Raceto-the-Bottom? Some quantitative lessons from the EU. Journal of Monetary Economics, 52(1), 163-204. https://dx.doi.org/10.1016/j. jmoneco.2004.07.002.

Ministry ofForeignandEuropeanAffairs of the Slovak Republic. (2017). Economic Information about the Territory: Republic of Lithuania. Retrieved January 17, 2018, form https://www. mzv.sk/documents/750116/620840/Litva+-+ek onomick $\% \mathrm{C} 3 \% \mathrm{~A} 9+$ inform $\% \mathrm{C} 3 \% \mathrm{~A} 1$ cie+o+terit \%C3\%B3riu+2017.

Musgrave, R. (1959). The Theory of Public Finance. New York: McGraw.

Oates, W. E. (1972). Fiscal Federalism. New York: Harcourt.

Oates, W. E. (1985). Searching for Leviathan: An Empirical Study. The American Economic Review, 75(4), 748-757.

Oates, W. E. (1989). Searching for Leviathan: A Reply and Some Further Reflections. The American Economic Review, 79(3), 578-583.

Oates, W. (1999). An essay on fiscal federalism. Journal of Economic Literature, 37(3), 1120-1149. https://dx.doi.org/10.1257/ jel.37.3.1120.

Oates, W. E. (2005). Toward A SecondGeneration Theory of Fiscal Federalism. International Tax and Public Finance, 12(4), 349-373. https://dx.doi.org/10.1007\%2 Fs10797-005-1619-9.

OECD. (2016). A Taxonomy of Tax Autonomy. OECD Fiscal Decentralization Database. Retrieved October 10, 2016, from https://www.oecd.org/ctp/federalism/ oecdfiscaldecentralisationdatabase.htm\#A_ Title.

Panizza, U. (1999). On the Determinants of Fiscal Centralization: Theory and Evidence. Journal of Public Economics, 74(1), 97-139.

Provazníková, R. (2015). Financování měst, obcí a regionů. Praha: Grada Publishing.

Razin, A., \& Sadka, E. (2011). Tax Competition and Migration: The Race-to-theBottom Hypothesis Revisited [NBER Working Paper Series. No. 11670]. Retrieved December 
01, 2016, from https://www.uclouvain.be/cps/ ucl/doc/econ/documents/textesadka.pdf.

Řezánková, H., Húsek, D., \& Snášel, V. (2009). Zhluková analýza dat (2nd ed.). Príbram: Professional Publishing, PBTisk.

Reuters. (2012, October 27). Hungary govt to take on 1.7 billion pounds of municipal debt. Business News. Retrieved January 18, 2018, from http://uk.reuters.com/article/uk-hungarylocalgovts-idUKBRE89Q05920121027.

Rodden, J. (2003). Reviving Leviathan: Fiscal Federalism and Growth of Government. International Organization, 57(4), 695-729. https://dx.doi.org/10.1017/ S0020818303574021.

Rodríguez-Pose, A., \& Ezcurra, R. (2011). Is Fiscal Decentralization Harmful for Economic Growth? Evidence from the OECD countries. Journal of Economic Geography, 11(4), 619643. https://dx.doi.org/10.1093/jeg/lbq025.

Rodríguez-Pose, A., \& Krøijer, A. (2009). Fiscal decentralization and Economic Growth in Central and Eastern Europe [LEQS Paper No. 12/2009]. The London School of Economics and Political Science. Retrieved September 30, 2016, from http://www.Ise.ac.uk/ europeanInstitute/LEQS\%20Discussion $\% 20$ Paper\%20Series/LEQSPaper12.pdf.

Samuelson, P. A. (1954). The Pure Theory of Public Expenditure. Review of Economics and Statistics, 36(4), 387-389. https://dx.doi. org/10.2307/1925895.

Samuelson, P. A. (1955). Diagrammatic Exposition of theory of Public Expenditure. Review of Economics and Statistics, 37(4), 350-356. https://dx.doi.org/10.2307/1925849.

Shah, A. (2007). Introduction: The Principles of Fiscal federalism. In A. Shah (Ed.), The Practice of Fiscal Federalism: Comparative Perspectives (pp. 3-42). McGill-Queen's University Press.

Sinicakova, M., Sulikova, V., \& Gavurova, B. (2017). Twin deficits threat in the European Union. E\&M Ekonomie a Management, 20(1), 144-156. https://dx.doi.org/10.15240/tul/001/2017-1-010.

Sinicakova, M., \& Gavurova, B. (2017). Single Monetary Policy versus Macroeconomic Fundamentals in Slovakia. Ekonomický časopis, 65(2), 158-172.

Stansel, D. (2006). Interjurisdictional competition and local government spending in U.S. metropolitan areas. Public Finance Review, 34(2), 173-194. https://dx.doi. org/10.1177/1091142105283576.
Statistics Estonia. (2017). Population of counties after administrative reform. Retrieved January 18, 2018, from https://www.stat.ee/ news-release-2017-121.

Stegarescu, D. (2004). Economic Integration and Fiscal Decentralization: Evidence from OECD Countries [ZEW Discussion Paper No. 04-86]. Centre for European Economic Research. Retrieved August 25, 2016, from http://hdl.handle.net/10419/24093.

Stegarescu, D. (2005). Public Sector Decentralisation: Measurement Concepts and Recent International Trends. Fiscal Studies, 26(3), 301-333. https://dx.doi.org/10.1111/ j.1475-5890.2005.00014.x.

Široký, J. (2009). Daně v Evropské unii. Praha: Linde.

Thießen, U. (2003). Fiscal decentralization and economic growth in high income OECD countries. In $18^{\text {th }}$ Annual Congress of the European Economic Association (EEA). SEStockholm, 20-24 August 2003.

Tiebout, Ch. (1956). A pure theory of local expenditures. The Journal of Political Economy, 64(5), 416-424. https://dx.doi. org/10.1086/257839.

Wagner, A. (1876). Grundlegung der politischen Okonomie. Bd. 1: Grundlagen der Volkswirthschaft (3rd ed.). Leipzig.

World Bank. (2001). Fiscal Decentralization Indicators. Retrieved September 15, 2016, from http://www1.worldbank.org/publicsector/ decentralization/fiscalindicators.htm.

Ząbkowicz, A. (2017). Economics and groups: methodological individualism and collective action. Oeconomia Copernicana, 8(1), 7-20. https://dx.doi.org/10.24136/oc.v8i1.1.

Ing. Lenka Maličká, Ph.D. Technical University of Košice Faculty of Economics Department of Finance Slovakia lenka.malicka@tuke.sk

Ing. Slavomíra Martinková Technical University of Košice Faculty of Economics Department of Finance Slovakia slavomira.martinkova@tuke.sk 


\section{FISCAL DECENTRALIZATION DETERMINANTS: ANALYSIS OF THE EU COUNTRIES'CLUSTERED SAMPLE IN PERIOD 1995-2015}

\section{Lenka Maličká, Slavomíra Martinková}

Fiscal decentralization as a shift of decision-making powers from the central level of government to lower government levels is an object of wide research. In this field there is a discussion ranging from the eligibility of fiscal decentralization, its advantages and threats, to searching for the fiscal decentralization's impact on certain macroeconomic indicators. Research focusing on investigating for fiscal decentralization determinants has not clear answer to this question. It considers various indicators often with their ambiguous impact on fiscal decentralization. In this paper, the problem of fiscal decentralization determinants is investigated on the EU countries sample in period 19952015. EU countries are divided into groups according to their fiscal decentralization average degree using the cluster analysis. Fiscal decentralization different measures refer on the expenditure, revenue, tax and grant decentralization. For each cluster a panel model is estimated to reveal an influence of selected variables on fiscal decentralization, while fiscal decentralization as dependent variable is measured by chosen various measure. Sensitivity of the estimation results on the fiscal decentralization measurement is obvious. Obtained results partially support assumptions given on basics of related literature. Significant appearance of the economy openness variable, GDP per capita growth and inflation rate, public and local debt variable and variable based on dependency ratio, and population density is influenced by construction of the fiscal decentralization indicator. It might explain the disunited character of observed FEM and REM results, additionally the turn of coefficient sign comparing fiscal decentralization measures postulates certain common tendencies revealing the fiscal decentralization character and conditions.

Key Words: Public sector, fiscal federalism, fiscal decentralization, cluster analysis, panel data.

JEL Classification: $H 77$.

DOI: 10.15240/tul/001/2018-2-011 